\title{
What is the potential for biogas digesters to improve soil fertility and crop production in Sub-Saharan Africa?
}

3

4

Jo Smith ${ }^{a *}$, Assefa Abegaz ${ }^{b}$, Robin Matthews ${ }^{c}$, Madhu Subedi ${ }^{c}$, Bob Orskov ${ }^{c}$, Vianney Tumwesige ${ }^{d}$, Pete Smith ${ }^{a}$

a Institute of Biological \& Environmental Science, University of Aberdeen, 23 St Machar Drive, Aberdeen, AB24 3UU; ${ }^{b}$ Addis Ababa University, Department of Geography \& Environmental Studies, Addis Ababa, Ethiopia; ${ }^{c}$ The James Hutton Institute, Craigiebuckler, Aberdeen, UK AB15 8QH; ${ }^{d}$ Centre for Research in Energy and Energy Conservation, Makerere University, Kampala, Uganda

"Corresponding author: Jo Smith, University of Aberdeen, 23 St Machar Drive, Aberdeen, AB24 3UU, UK. Tel: (+44) 1224 272702. Fax: (+44) 1224 272703. Email: jo.smith@abdn.ac.uk.

\section{ABSTRACT}

Three alternative soil amendments of organic wastes are considered: application of untreated animal manures, bioslurry from biogas digestion, composted materials, and biochar produced by pyrolysis cook-stoves. Application of untreated manures provides high input of available nutrients, which results in an initial flush in crop growth. However, risks of losing nutrients are high because manure is usually applied before sowing to avoid reduced yields due to phytotoxicity, resulting in increased losses by leaching or volatilization. Furthermore, the heterogeneous nature of untreated manures results in immobilization of nutrients by carbon-rich materials. A greater amount of nutrients are potentially available to crops from applied bioslurry. Typically $5-10 \%$ of the nitrogen is lost during anaerobic digestion, but bioslurry provides immediately available nutrients that can be applied as needed, so reducing risks of nutrient loss. If, however, bioslurry was applied in a single dose, losses would be similar in magnitude to untreated manures. Risks of nutrient losses are also lower when wastes are applied as composts, but in contrast to bioslurry, this is because the concentration of immediately available nutrients is very low, most nutrients being held in organic form that will become available only slowly over the growing season. Composts provide an option for single dose application, but a larger proportion of nitrogen is lost during composting (26-51\%) than during anaerobic digestion (5$10 \%)$. Losses of nitrogen during pyrolysis are also very high (70-90\%), but biochar can reduce losses of native soil nutrients by providing exchange sites that hold nutrients in the soil.

\section{Keywords}

\section{Biogas}

Soil fertility

Crop production

Sub-Saharan Africa

Anaerobic digestion

\author{
Abbreviations \\ $\mathrm{C}=$ Carbon \\ $\mathrm{CH}_{4}=$ Methane \\ $\mathrm{CO}_{2}=$ Carbon dioxide \\ $\mathrm{K}=$ Potassium \\ $\mathrm{N}=$ Nitrogen \\ $\mathrm{N}_{2} \mathrm{O}=$ Nitrous oxide \\ $\mathrm{NH}_{4}{ }^{+}=$Ammonium \\ $\mathrm{NO}_{3}^{-}=$Nitrate \\ $\mathrm{P}=$ Phosphorus \\ SSA = Sub-Saharan Africa
}




\section{Introduction}

Food requirements across Sub-Saharan Africa (SSA) are expected to increase over the next 50 years with increases in the population. Recent global projections indicate that the population of SSA will double from today's level, reaching close to 2 billion by the year 2050, with half of this number being under 25 years of age [1]. If SSA is to meet the hunger-related Millennium Development Goals, FAO [2] estimates that it will need adequate food supplies for 18 million additional people each year, and to improve the nutritional status of 94 million people. This is the equivalent of achieving a $4.6 \%$ annual growth in food supplies [3]. Added to this, the increasing demand for livestock products in SSA and the lower efficiency of food production by livestock compared to direct cropping [4] are likely to further increase pressure on land used to grow food. Tilman et al. [5] forecast a 100-110\% increase in global crop production by 2050 , with much of this expansion occurring in poorer nations. If the required growth in food supplies is to be achieved, all resources that impact crop production must be targeted and recycled to avoid any waste or loss to the wider environment [6].

At the same time, solid organic waste removal has become an ecological problem, particularly in urban areas. In a review of the average solid waste generation rate in 23 developing countries, Troschinetz and Mihelcic [7] quantified the average total solid waste generated by each person each day to be $0.77 \mathrm{~kg}$ and increasing. Similarly, Couth and Trois [8] estimated the total solid waste generated by each person in Africa to be $0.63 \mathrm{~kg}$, with an average organic content of $56 \%$. Solid organic waste is a potential source of nutrients that, instead of being disposed of, should be used to improve crop production. Mihelcic et al [9] estimated that human urine and feces could account for $22 \%$ of the total global phosphorus (P) demand in 2009. Biogas digesters have potential to treat this organic waste, greatly increasing the potential for re-use, but whether a net improvement in conservation of resources is achieved depends on the possible alternative uses of the organic wastes.

This paper explores the available evidence for the potential impact of biogas digesters on soil fertility and crop production in SSA compared to the impacts of other uses for organic wastes. Factors that control crop production include uptake of nutrients, water and oxygen, light interception, and temperature. The environmental constraints that directly impact these factors include availability of nutrients, organic matter content of the soil and water availability. The widespread introduction of biogas digesters is likely to have an impact on all of these environmental constraints.

\subsection{Availability of nutrients}

Because the highest demand in most crops is for nitrogen $(N)$ and $P$, these nutrients most commonly limit crop growth [10,11]. Fertilizer applications, particularly of $N$ and $P$, can therefore significantly increase crop yields in SSA. In a meta-analysis of 90 peer-reviewed papers from journals and conference proceedings with information on control yields, yields after $\mathrm{N}$ fertilizer application, and fertilizer $\mathrm{N}$ rates in maize-based cropping systems in SSA, Vanlauwe et al. [12] noted increases in yields of up to $40 \mathrm{~kg}$ per $\mathrm{kg}$ of applied N. Phosphorus limitations are also widespread [13] and can be alleviated by application of mineral or organic fertilizers. Tests conducted by farmers in P deficient fields at Sadore in Niger showed that millet yields could be increased by more than $250 \%$ by the use of $P$ fertilizers [14]. In three soils in the northern highlands of Ethiopia, Assefa Abegaz [15] observed increases in barley yields of up to 90,69 and $90 \mathrm{~kg}$ per $\mathrm{kg}$ of applied N, P and potassium (K) respectively. Higher agronomic efficiency of applied fertilizers implies more efficient use of expensive chemical fertilizers, higher economic efficiencies (decreased production costs) and decreased potential environmental risks. Increased recycling of nutrients through application of the bioslurry output from biogas digesters could impact the nutritional status of crops and so greatly improve yields.

\subsection{Organic matter content of the soil}

Crop productivity is intimately linked to the soil organic matter content [16], which influences soil physical, chemical and biological properties, as well as indigenous soil nutrient supply $[17,18]$. Agricultural production in SSA is often limited by low organic matter content of the soil [19]. Lal [20] identified SSA as a global hotspot of soil degradation with a high priority for soil restoration and carbon (C) sequestration. It has been suggested that a critical limit for soil organic $\mathrm{C}$ concentration in most soils of the tropics is $1.1 \%$ (equivalent to $11 \mathrm{~g} \mathrm{~kg}^{-1}$ of dry soil) [21], but Nyamangara [22] indicated that on average in SSA, the organic $C$ content of the soil is less than $1 \%$. 
Soil organic matter influences the long term losses of nutrients by erosion, leaching and gaseous emissions, and when decomposed by micro-organisms can also provide a slow release source of nutrients to plants. Lal [20] estimated that $1 \mathrm{t}$ of $\mathrm{C}$ sequestered as soil organic matter will hold on average $80 \mathrm{~kg} \mathrm{~N}, 20 \mathrm{~kg} \mathrm{P}$ and $15 \mathrm{~kg} \mathrm{~K}$, and observed that an increase in arable soils of $1 \mathrm{t} \mathrm{ha}^{-1}$ could increase crop yields by 20 to $40 \mathrm{~kg} \mathrm{ha}^{-1}$ for wheat, 10 to $20 \mathrm{~kg} \mathrm{ha}^{-1}$ for maize, and 0.5 to $1 \mathrm{~kg} \mathrm{ha}^{-1}$ for cowpeas.

As well as the direct effect of improved nutrient supply, increases in yield associated with organic applications are due to the action of soil organic matter on aggregate structure, so influencing the water holding capacity and aeration of the soil, and affecting root development down the soil profile, which determines the amount of nutrients and water available to the growing plant. Significant improvements in crop yields were observed when fertilizer was applied in conjunction with crop residue mulch [23], trees [24] or with manure or compost [12], suggesting that additional factors to nutrient supply determine the impact of soil organic matter on crop yields. Assefa Abegaz [15] reported that increases in the agronomic efficiencies of applied $\mathrm{P}$ and $\mathrm{K}$ fertilizers were much greater in fields with higher soil organic $\mathrm{C}$ contents. In long term experiments at Kabete, Kenya, Janssen [25] observed an increase in yield of $0.85 \mathrm{t} \mathrm{ha}^{-1}$ for each $\mathrm{g}$ soil organic $\mathrm{C}$ added per $\mathrm{kg}$ of soil. Farm demonstrations in different countries in SSA suggest that with good management of soil organic matter, it is possible to increase yields by up to five times [26].

The yield response at a particular site clearly depends on the current $C$ and nutrient status of the soil with the yield response differing with site. It should also be noted that the quality as well as the quantity of organic material applied to the soil is important in determining the yields of subsequent crops. Reduced yields of maize crops have been observed following application of $\mathrm{C}$ rich cattle manure because these applications resulted in immobilization of the plant available $\mathrm{N}$ in the soil, so increasing rather than reducing the $\mathrm{N}$ limitation of the crop $[22,27]$.

\subsection{Availability of water}

Availability of water has a direct impact on crop productivity [28], and is determined by the climate and soil type. The quantity and patterns of rainfall impact the amount of water that is retained in the soil or is lost by runoff, so affecting the availability of water for plant uptake. Air temperature, humidity, solar radiation and wind speed impact the evaporation of water from the soil and evapotranspiration from the plant, so further impacting the availability of water. Soil texture and organic matter content also determine the water holding capacity and the amount of water that percolates through the soil [29]. Limitations in crop yield due to soil water availability are likely to be exacerbated by climate change [30]. Unless water management and water use efficiency are improved, water availability is predicted to be a key limitation to crop production over the next 50 years [31-38].

By providing a source of organic matter to the soil, widespread implementation of biogas digesters has potential to greatly improve water use efficiency. However, water is also required to mix the organic waste into a slurry that is suitable for anaerobic digestion, so pressures on water use could instead be exacerbated by the introduction of biogas digesters [39]. Some of the water used in the biogas digester can be recycled from household uses, but extra water may be required in order to achieve the optimum solid content for digestion. Orskov et al. [40] suggest that a typical 4-person household would require $88-100 \mathrm{dm}^{3}$ per day to run a biogas digester, which is equivalent to $\sim 65-70 \%$ additional household water use. Given the average time spent collecting water each day of 134 minutes, this would equate to an additional 5 hours labor per household each day [40]. The water requirement for anaerobic digestion is therefore an important factor in determining the feasibility of this method of organic waste treatment and requires further investigation.

\subsection{Different uses of organic wastes}

Organic wastes are a limited resource in SSA, that are used for a range of competing objectives [41]. Using bioslurry from biogas digestion as an organic fertilizer could potentially improve crop yields, by supplying organic matter to the soil, which improves soil structure and water holding capacity, and by supplying nutrients to the crop. However, whether a net improvement in crop production is actually achieved depends on how the organic waste would otherwise have been used and the impact of reducing these uses on the soil and crops. In many parts of SSA, there is no tradition for using 
organic wastes in crop production [42], and this could be a major constraint to improving yields, but in many other areas, there is a long history of farmers applying organic wastes to their fields, with documented evidence for example in Ouagadougou in Burkina Faso [43], Bamako in Mali [43] and Kano in Nigeria [44] and manure production being given by smallholder farmers in some regions as being a major reason for keeping cattle [45]. Waste management practices differ between rural and urban areas, with a large fraction of the rural waste being scavenged and recycled, whereas the waste often presents a problem of disposal in urban areas [8]. Export of wastes to rural areas could provide a solution to waste disposal, while returning nutrients back to the areas used to grow crops [43].

In rural areas, there is strong competition in the use of animal manures and straw for household energy provision or for soil fertility management. Traditionally, organic wastes have been dried and burnt as a fuel, leaving ash residues that do not greatly enhance the organic matter or $\mathrm{N}$ content of the soil. Another traditional use is as a building material; this application means that none of the $\mathrm{C}$ or nutrient content of the organic wastes is returned to the soil. If this organic waste was instead used to produce biogas, significant increases in $\mathrm{C}$ and nutrient inputs to the soil are likely, as well as providing a convenient and clean source of household energy.

With other uses, the impacts of diverting the organic wastes to biogas production are not so easily determined. Some types of organic wastes can be used to produce energy by burning in pyrolysis cook-stoves or larger scale pyrolysis plants [46]. Pyrolysis occurs when organic materials are burnt under low oxygen conditions [47,48], releasing energy. The process also produces a highly resistant form of $C$, known as biochar, which can be further combusted or incorporated into the soil [49]. When biochar is incorporated into the soil, it has been reported to enhance plant growth [50-54], therefore benefitting both energy and crop production. If energy production is considered less important than soil fertility management, organic wastes can be composted under aerobic conditions to provide an important source of organic fertilizer. When composts are incorporated in the soil, improvements in crop yield are observed due to the supply of nutrients and organic matter. Heat is released during composting, but capture and utilization of this energy is less easily achieved than with pyrolysis or anaerobic digestion.

Pyrolysis, aerobic composting and anaerobic digestion all have potential to improve crop productivity and soil fertility by adding organic matter and nutrients to the soil. A direct comparison is needed of the improvement in soil fertility and crop yields achieved using the same quantity of starting material if applied untreated, or applied after treatment by the different methods. In this paper, we review the available evidence for comparing the impacts of different treatments of organic wastes on the availability of nutrients to crops.

\section{Factors affecting availability of nutrients from organic wastes to crops}

\subsection{Nutrient release characteristics of organic wastes}

The nutrients held in organic wastes can be categorized as immediately available, rapidly released, slowly released or unavailable $[29,55]$. Nutrients that are immediately available to the plant are in the form of a small mobile ion, such as ammonium $\left(\mathrm{NH}_{4}^{+}\right)$that can readily be taken up by the plant without the need for further chemical or biological conversion. Rapidly released nutrients will be released to the plant by the soil micro-organisms in the first years following application. Ammonium, nitrate $\left(\mathrm{NO}_{3}^{-}\right)$, phosphates $\left(\mathrm{HPO}_{4}{ }^{2-}\right.$ and $\left.\mathrm{H}_{2} \mathrm{PO}_{4}^{-}\right)$, and sulfate $\left(\mathrm{SO}_{4}^{2-}\right)$ are the main forms of nutrients provided by this microbial conversion of organic compounds into inorganic compounds. Slowly released nutrients will become available to the plant over a much longer period. Unavailable nutrients are in a form that cannot be accessed by the soil micro-organisms, either due to being in a recalcitrant form or due to physical protection by other recalcitrant materials. The release characteristics of nutrients from the treated and untreated organic wastes depend on the amount of nutrients held in each of these forms. The different treatment processes have distinctive impacts on the different categories of nutrients [56].

\subsection{Loss and transformation of the nutrients available in organic wastes}

The nutrients in the organic wastes that are categorized as immediately available are in a form that can be taken up by the plant, but may also be susceptible to loss by physical processes or use by 
micro-organisms, and this will further affect the availability of nutrients to the plant. Cations, such as of aluminosilicates (clay minerals). By contrast, anions, such as $\mathrm{NO}_{3}{ }^{-}, \mathrm{PO}_{4}{ }^{3-}, \mathrm{SO}_{4}{ }^{2-}, \mathrm{B}(\mathrm{OH})_{4}{ }^{-}$and $\mathrm{MoO}_{4}{ }^{2-}$ are held on the less numerous $\mathrm{pH}$-dependent positive sites on the edges of aluminosilicates and the surfaces of sesquioxides. These sites only hold a net positive charge when the $\mathrm{pH}$ is below the point of zero charge, so in non-acidic soils, anions are usually more susceptible to loss by leaching [57]. In the highly weathered tropical soils of SSA, the clay fraction is often dominated by the aluminoilicate, kaolinite, and by sesquioxides [58]. Aluminium tends to replace iron in the structure of iron oxide minerals, breaking up the crystalline structure, reducing the size of particles, and increasing the surface area, so the variable charge in these soils is usually high [58]. As tropical soils undergo more weathering, more iron and aluminium oxides form, resulting in an increase in the number of positively charged sites holding anions at a given $\mathrm{pH}$ and a decrease in the number of negatively charged sites holding cations [58]. The amount of leaching is dependent on rainfall and the texture of the soil, so the availability of anionic forms of nutrients is highly dependent on these factors, as well as on the soil $\mathrm{pH}$, mineral and organic matter content.

Although cations such as $\mathrm{NH}_{4}{ }^{+}$are less subject to loss by leaching, micro-organisms may immobilize these nutrients during decomposition of $\mathrm{C}$ rich organic matter, so making them unavailable to the plant [59]. Other micro-organisms may convert $\mathrm{NH}_{4}{ }^{+}$to $\mathrm{NO}_{3}^{-}$making the $\mathrm{N}$ more susceptible to loss by leaching [60]. The nutrients in organic wastes that are categorized as rapidly or slowly released are only made available to plants following microbial decomposition of the organic waste, which mineralizes associated nutrients if they are in high concentration in the organic matter. As a rough guide, if the C:N mass ratio of the decomposable organic matter is less than $8: 1$, the material will tend to release (mineralize) plant available $\mathrm{N}$ in the soil, whereas materials with $\mathrm{C}: \mathrm{N}$ mass ratios greater than 35:1 will tend to immobilize $N$ [61]; materials with a C:P mass ratio less than 200:1 tend to mineralize plant available $P$, whereas materials with $C: P$ mass ratios greater than $300: 1$ tend to immobilize $P$ [29].

These microbial reactions are dependent on the soil temperature, moisture, $\mathrm{pH}$, salinity and clay content $[60,62]$. As temperature increases, the rate of decomposition tends to increase exponentially, up to the point where microbial activity is inhibited by the high temperatures [63]. Similarly, the rate of decomposition tends to increase with soil moisture, up to field capacity [64]. Above field capacity, as the soil becomes saturated, the rate of decomposition declines, so slowing the further release of nutrients. The decomposition process is also inhibited in very acidic soils [65], and in soils that are highly saline [66]. The clay content has an impact on the retention of $\mathrm{C}$ from the decomposing material, a higher clay content releasing a lower proportion as $\mathrm{CO}_{2}$ and retaining more organic matter in the soil [67]. This then has an impact on the rate of release of nutrients, since a higher clay content retains more nutrients associated with the retained soil organic matter and releases less nutrients to the plant. The nutrients remain in the soil, but will only be released to the plant after further cycles of decomposition of the soil organic matter.

\section{Fresh organic wastes}

\subsection{Composition of fresh organic wastes}

Animal manures are often applied as fresh material because of their high concentration of immediately available $\mathrm{N}$. The composition of the fresh animal manure is dependent on the type of feed, bedding and the type of animal [68]. At $40-70 \%$ of the total $\mathrm{N}$, uric acid is the most abundant form of $\mathrm{N}$ in fresh poultry manure, with smaller amounts of urea and $\mathrm{NH}_{4}{ }^{+}$also being present [69]. The uric acid is decomposed to urea by the action of aerobic bacteria [70]. Cattle and pigs excrete approximately $50 \%$ of their $\mathrm{N}$ intake as urea, with a higher intake resulting in a larger proportion of the $\mathrm{N}$ intake being excreted [71,72]. Many soil bacteria use the enzyme urease to catalyse the breakdown of urea into ammonia and carbon dioxide $\left(\mathrm{CO}_{2}\right)[73]$ :

$\mathrm{CO}\left(\mathrm{NH}_{2}\right)_{2}+\mathrm{H}_{2} \mathrm{O} \stackrel{\text { urease }}{\longrightarrow} \mathrm{CO}_{2}+2 \mathrm{NH}_{2}$

The ammonia may then either be lost as a gaseous emission or converted into $\mathrm{NH}_{4}{ }^{+}$by dissolving in the soil solution. 
$\mathrm{NH}_{\mathrm{a}}+\mathrm{H}_{2} \mathrm{O} \leftrightarrow \mathrm{NH}_{4}{ }^{+}+\mathrm{OH}^{-}$

Phosphorus in untreated manures occurs mainly in inorganic form; an analysis of manure from feedlot beef determined that organic $P$ averaged only $25 \%$ of the total $P$ in the manure [74]; similar results were observed for dairy manure, poultry manure and swine slurry, with over $63 \%$ occurring in inorganic $\mathrm{P}$ form [75]. However, most of the inorganic $\mathrm{P}$ is insoluble, with water soluble $\mathrm{P}$ observed by Eghball [74] to constitute only $8 \%$ of the total. The N:P mass ratio of organic wastes is usually higher than the N:P requirement of most crops; this can result in a high residue of $P$ being left in the soil after repeated manure applications which can be susceptible to loss by leaching [76]. Because $\mathrm{K}$ in plants remains dissolved in cell sap, $\mathrm{K}$ in manures is also present mainly in the form of $\mathrm{K}^{+}$[77].

Despite the high concentration of immediately available nutrients in manure, to achieve maximum crop production, it is usually necessary to apply fresh organic wastes a number of days before sowing to allow soil micro-organisms to degrade labile organic matter, avoiding the adverse affects of nutrient immobilization, and to reduce phytotoxicity [78]. During the period between applying the organic waste and sowing, the immediately available nutrients are highly susceptible to loss, for instance by leaching of highly mobile forms of the nutrients, such as $\mathrm{N}_{\text {in }} \mathrm{NO}_{3}{ }^{-}$, which is produced by nitrification of the $\mathrm{NH}_{4}{ }^{+}$available in fresh animal wastes [79].

Carbon rich plant residues, such as cereal straw, can contain appreciable amounts of nutrients [59]. However, release of the nutrients requires the organic material to be decomposed by microorganisms. Because of the high C:nutrient ratios, the soil micro-organisms using the residue as an energy source will require more nutrients than are available in the residue. These nutrients are scavenged from the surrounding soil, and so incorporation of $\mathrm{C}$ rich plant residues can actually result in short term nutrient deficiency in crops before the nutrients are finally released [59]. Therefore, $C$ rich plant residues should not be applied directly to crops without an additional source of available nutrients.

\subsection{Fresh organic wastes in Sub-Saharan Africa}

Animals in farming systems in SSA are typically fed materials that are low in nutrients, which will result in a relatively low content of immediately available nutrients in the manure produced [72]. The availability of nutrients to plants will depend on the mixture of wastes incorporated in the soil. Kaboré et al. [80] measured the $\mathrm{N}$ content of a number of organic wastes used in SSA and found a high C:N mass ratio in tree leaves (43.6:1) and paper (372.1:1), suggesting initial immobilization of $\mathrm{N}$ will occur, but a low C:N mass ratio in household refuse (8.7:1) and slaughter-house wastes (15.1:1), which will tend to release N. Organic wastes from rural households in SSA will tend to be composed of animal manure, household refuse and tree leaves, suggesting that if applied untreated, some degree of immobilization of the immediately available $\mathrm{N}$ will occur, but there may be longer-term mineralization of $\mathrm{N}$ from the decomposing household refuse.

\section{Composts}

\subsection{Composition of composts}

Composting usually reduces the amount of immediately available nutrients in animal manures, converting them into rapidly and slowly released forms and concentrating the nutrients by releasing $\mathrm{CO}_{2}$ [56]. The composition of nutrients in composts is driven by the aerobic decomposition reactions, the relative balance of nutrients compared to the requirements of the micro-organisms determining whether nutrients are mineralized or immobilized. In experiments conducted by Paul and Beauchamp [81], between 57 and $76 \%$ of the $\mathrm{N}$ in liquid manure was present as $\mathrm{NH}_{4}{ }^{+}$, between 19 and $34 \%$ in solid manure, and less than $3 \%$ in compost. Nitrate was also present in composted materials, but accounted for a low proportion of the $\mathrm{N}$ at less than $5 \%$ of the total $\mathrm{N}$ [81]. By contrast, the proportion of organic $\mathrm{P}$ in composts tends to be lower than in the untreated manure; organic $\mathrm{P}$ accounted for only $16 \%$ of the total $P$ in composts of manure from feedlot beef, compared to $25 \%$ in the untreated manure [74]. This suggests mineralization of the $\mathrm{P}$ occurs during the composting process. Watersoluble $\mathrm{P}$ also decreased during composting from $8 \%$ to only $5 \%$, the mixing action during composting, converting $P$ from soluble to insoluble forms of $P$ [74]. Potassium remains in the form of $\mathrm{K}^{+}[77]$, so availability to the plants remains largely unchanged by the composting process. 
Despite the lower concentration of immediately available nutrients, the total nutrients made available to crops by composts may be greater than when fresh organic wastes are applied. This is because composting allows additional $\mathrm{C}$ rich organic wastes to be used as a soil amendment by adjusting the $\mathrm{C} / \mathrm{N}$ ratio of the compost to around 25, the ideal composition for composting [82]. As discussed above, these $\mathrm{C}$ rich materials could not be incorporated in the soil without previous treatment because the microbial decomposition would cause nutrient deficiencies in the crops. Composts also retain more nutrients in the soil / crop system by providing a gradual release of nutrients to the crop over the course of the growing season, so avoiding immobilization or large leaching or gaseous losses of available nutrients from the soil.

\subsection{Losses during composting}

Some available nutrients may be lost during the composting process due to volatilization and other gaseous emissions [83], especially if animal manures are composted without a bulking agent [84]. Where compost heaps are uncovered, as is often the case in Africa, leaching losses may also become important [85]. Leaching losses of $\mathrm{P}$ during composting tend to be low because the mixing action during composting encourages the conversion of soluble $P$ to insoluble forms of $P$ [74]. The amount of $\mathrm{N}$ lost during composting is highly variable, and depends on the type of feedstock, the temperatures achieved during composting, and the degree of aeration. When household waste was composted for 168 days, mostly under thermophilic conditions, Kirchmann and Widén [86] observed $51 \%$ of the initial total $\mathrm{N}$ was lost, but when it was mixed with green waste, only $26 \%$ was lost. Under mesophilic conditions, Eklind and Kirchmann [87] observed that $62 \%$ of the initial $\mathrm{N}$ was emitted during 570 days of composting. The coexistence of anaerobic and aerobic conditions have been observed in large, extensively managed compost heaps [88], resulting in emissions of the greenhouse gas, nitrous oxide $\left(\mathrm{N}_{2} \mathrm{O}\right)$, especially if the storage time for the compost is prolonged. The impact of $\mathrm{N}_{2} \mathrm{O}$ in the atmosphere on climate, as measured by the radiative forcing potential, is 310 times that of $\mathrm{CO}_{2}$ [89], so large emissions of $\mathrm{N}_{2} \mathrm{O}$ should be avoided by regular turning and mixing of the heap. However, losses by volatilization and leaching may increase when the heap is turned; Martin and Dewes [90] observed that $49 \%$ of the total $\mathrm{N}$ was lost as $\mathrm{NH}_{3}$ during turning, with more being lost by leaching if conditions were wet.

\subsection{Composts in Sub-Saharan Africa}

Sub-Saharan Africa provides special conditions that impact the success of composting [80]: hot climatic conditions may increase the rate of decomposition, but may also increase evaporation from the compost heap, requiring extra water to be added to maintain the decomposition processes; dry and nutrient deficient materials may increase the time required for compost to mature. Kaboré et al [80] observed that in pit composts in SSA, stabilization of organic matter occurred more rapidly in mixtures including slaughter-house wastes, was progressive in mixtures with household wastes, but was very slow in composts of tree leaves. Immediately available $\mathrm{N}$ was highest in composts containing slaughter-house wastes, and remained low in composts made from household wastes or tree leaves. In the small-scale rural household setting, it is likely that the composts will be derived from household wastes, nutrient deficient animal manures and tree leaves, so it is expected that immediately available nutrients in the compost will remain low, nutrients being released to the plant by microbial action over the growing season. This will also tend to result in lower losses of nutrients during the composting process, so it is likely that composting will be a highly efficient method of retaining nutrients in the soil / crop system, although there may be a tendency for immobilization to occur if the composts are incorporated when they are not sufficiently mature.

\subsection{Availability of nutrients from composts compared to fresh organic wastes}

When compared directly with incorporation of the fresh organic wastes typical of SSA, using composted materials will tend to increase the availability of nutrients to the crops by increasing the range of materials that can be amended to the soil, and reducing volatilization and immobilization losses by avoiding high concentrations of $\mathrm{NH}_{4}{ }^{+}$in the soil. Losses during the treatment process are likely to be more than offset by the losses that occur when fresh organic wastes are applied to the soil. This can be demonstrated by estimating the susceptibility of the nutrient to loss when applied either as untreated or composted organic waste.

The susceptibility to loss can be expressed as the average concentration of available nutrient in the 
soil over any given time. Over the course of the growing season, this is a function of the maximum potential uptake of nutrients by the crop and the pattern of release of available nutrient from the organic waste. The maximum potential uptake of nutrients by the crop can be estimated from the crop demand for nutrients. For example, $\mathrm{N}$ demand can be represented by a simple sigmoid curve [61],

$$
U=\left(U_{\mathrm{m}}^{-1 / p}+\mathrm{e}^{-f d}\right)^{-p}
$$

where $U$ is the cumulative crop $N$ demand during the growing season $\left(\mathrm{kg} \mathrm{ha}^{-1}\right), U_{\mathrm{m}}$ is the total $\mathrm{N}$ demand at the end of the growing season $\left(\mathrm{kg} \mathrm{ha}^{-1}\right), p$ is a shape factor (here set to 0.15), $f$ is a rate constant for demand (here set to 0.375 ), and $d$ is the number of days since sowing. Similar uptake curves for other crops and different nutrients can be established using different values of $p$ and $f$; a crop that has a higher nutrient demand in the early season will use higher values of $p$ and $f$. If all $\mathrm{N}$ required by the crop is available at the start of the growing season, after $\mathrm{N}$ is removed according to Eqn.1, the average concentration of available $\mathrm{N}$ over the growing season is $66 \%$ of that applied. This can be taken as a measure of the susceptibility of the available $\mathrm{N}$ to loss. This would be the case if an untreated organic waste containing $C$ rich materials, such as tree leaves (resulting in no net mineralization over the growing season), was applied before sowing to avoid phytotoxicity. If the available $\mathrm{N}$ was applied in split applications throughout the season, the susceptibility to loss would decrease to a theoretical minimum value of $22 \%$ of the applied available N. This would be the case if the untreated waste was applied in multiple equal-sized split applications, although applying untreated manure in this way would not be a realistic management option. The release of nutrients from composted organic wastes can be considered in the same way as split applications of untreated waste, except that the pattern of release is likely to closely follow the requirements of the crop as the same environmental drivers determine crop demand and nutrient release, so the susceptibility to loss is likely to be even less than this theoretical minimum value of $22 \%$. The total losses from composts are given by the sum of the treatment loss and the losses from the soil, after treatment losses have been accounted for. Where losses during thermophilic composting are reported to range from $26 \%$ $51 \%$ [86], if all the remaining $N$ that is susceptible to loss from the soil is indeed lost, the total losses come to $43 \%$ to $61 \%$, with an average total loss of $52 \%$. This is significantly lower than the potential losses from soils following application fresh wastes of $66 \%$. While at some sites, not all nutrients that are susceptible to loss will be removed from the crop system, in tropical soils, if temperature and rainfall are high, a high proportion is expected to be lost by volatilization and leaching, especially in soils that are deficient in organic matter. Even without accounting for the likely increased range of materials that can be amended to the soil through composting, the reduction in losses from the soil is likely to significantly increase the nutrients available to the crop.

\section{Bioslurry produced by anaerobic digestion}

\subsection{Composition of bioslurries}

Anaerobic digestion similarly concentrates the nutrients that are initially in rapidly and slowly released forms by release of $\mathrm{C}$ during decomposition, but this time the $\mathrm{C}$ is released as methane $\left(\mathrm{CH}_{4}\right)$. The stability of organic matter is increased, but the C:nutrient ratio decreases, resulting in a product with a high content of rapidly released nutrients [91]. In contrast to aerobic composting, because oxygen rather than nutrients limit decomposition, anaerobic digestion tends to increase the content of immediately available $\mathrm{N}$, in the form of $\mathrm{NH}_{4}{ }^{+}[77,91]$. Kirchmann and Witter [56] measured $\mathrm{NH}_{4}{ }^{+}-\mathrm{N}$ concentrations in anaerobically digested materials of $50-75 \%$ of the total $\mathrm{N}$. Similar results were reported by Schievano et al. [92]. Precipitation of insoluble inorganic P during anaerobic digestion tends to reduce the concentration of immediately available $P$ and micronutrients [77], although this does not usually result in $\mathrm{P}$ deficiency in crops [93,94], perhaps because the N:P ratio in the untreated manure is higher than the N:P requirement of most plants [76]. Volatile fatty acids and other labile organic compounds are formed as intermediates in the anaerobic digestion process $[95,96]$. If these compounds are still present when bioslurry is applied to the soil, they provide a readily available source of $\mathrm{C}$, which could result in the available nutrients being immobilized or lost from the soil [97]. However, if care is taken to avoid too rapid a throughput of the organic waste, so circumventing a high content of these intermediate compounds, bioslurry provides an excellent source of immediately available nutrients that can be applied directly to crops when the crop needs additional nutrients, and a rapid crop response to the applied bioslurry will result. 


\subsection{Losses during anaerobic digestion}

Losses of nutrients during the digestion process may be expected to be less from anaerobic digesters than from compost heaps due to the use of an airtight vessel. Biogas is generally composed of $48-$ $65 \% \mathrm{CH}_{4}, 36-41 \% \mathrm{CO}_{2}$, up to $17 \%$ nitrogen gas, $<1 \%$ oxygen gas, $32-169 \mathrm{ppm}$ hydrogen sulphide and traces of other gases [98]. Therefore losses of nutrients other than $\mathrm{N}$ during this process can be expected to be small. In measuring nutrient losses in large centralized biogas plants in Europe, Möller et al. [99] found that $P$ and $K$ losses during digestion were negligible and $N$ losses occurred mainly as gaseous losses of ammonia during storage. Losses of $\mathrm{N}$ are reported by many authors to be very small, with most of the $\mathrm{N}$ being conserved in the bioslurry [100-103]. Schievano et al. [92] reported net losses of $5-10 \%$ of the total $\mathrm{N}$. Strik et al. [104] suggested losses could occur as migration of $\mathrm{NH}_{3}$ with the biogas flux. However, Schievano et al. [92] reported that less than $1 \%$ of the $\mathrm{N}$ loss occurred by this mechanism, suggesting that the remaining loss occurred by partial organic / inorganic matter sedimentation and subsequent retention in the digester. In experiments with batch reactors reported by Massé et al. [105], loss of $\mathrm{N}$ by sedimentation was observed to approach $30 \%$. Similar proportions $(2-9 \%)$ of $\mathrm{P}$ and $\mathrm{K}$ loss were observed during anaerobic digestion by Schievano et al. [92], again suggested to be due to sedimentation. These nutrients are removed from the bioslurry, but not entirely lost from the system as they can be returned to the soil when the digester is cleaned out, providing a potential slow release organic fertilizer.

\subsection{Bioslurries in Sub-Saharan Africa}

The nature of bioslurries produced by biogas digesters in SSA is impacted by the nature of the feedstock and the temperature of digestion [106]. Boadzo et al [99] reported that gas production from anaerobic digestion was highest from fats $\left(1.27 \mathrm{~m}^{3} \mathrm{~kg}^{-1}\right.$ total solids), followed by carbohydrates $(0.79$ $\mathrm{m}^{3} \mathrm{~kg}^{-1}$ total solids) and proteins $\left(0.7 \mathrm{~m}^{3} \mathrm{~kg}^{-1}\right.$ total solids), suggesting that the increase in concentration of nutrients in the bioslurry is highest in a fatty feedstock. However, the gas yield from the different types of feedstocks available in SSA varies over a very small range (municipal solid wastes $=0.1-0.2$, household waste $=0.2-0.3$, sewage sludge $=0.2-0.4$ and manure $=0.1-0.3 \mathrm{~m}^{3} \mathrm{~kg}^{-1}$ total solids [107]), and so the nutrient content of the feedstock is likely to have a greater impact than the amount of gas produced on the nutrient concentration in the bioslurry. Animals provided with a low nutrient feed produce manure with a lower nutrient content [72]. Digestates from feedstocks with a high degradability, such as cereal grains, poultry and pig manures with a diet high in concentrates, are characterized by a high $\mathrm{NH}_{4}^{+}$:total $\mathrm{N}$ ratio and low $\mathrm{C}: \mathrm{N}$ ratios $[77,108,109]$. Cattle manures or fibrous feedstocks low in $\mathrm{N}$ lead to a low $\mathrm{NH}_{4}{ }^{+}-\mathrm{N}$ :total $\mathrm{N}$ ratio [77,94]. The low nutrient contents of animal feeds commonly used in SSA, therefore, tend to reduce the immediately available nutrient content of the bioslurry. Biogas digesters in SSA usually operate in the mesophilic temperature range $\left(30-40^{\circ} \mathrm{C}\right)$, which allows anaerobic bacteria to continue to be active when the $\mathrm{NH}_{4}{ }^{+}$load is high, resulting in improved process stability as shown by reduced volatile fatty acid concentrations [110]. Because of the closed nature of the digester, a major advantage of a biogas digester is the potential to bring in additional sources of $\mathrm{N}$ rich materials, that might otherwise not be used for reasons of hygeine, for example human waste. For optimum biogas production, the $\mathrm{C}: \mathrm{N}$ ratio of the feedstock should be adjusted to within the range of 20-30:1 by combining waste materials [86]. This can be achieved, for instance, by adding urine or household wastes to the feedstock [111] and will result in a bioslurry with a higher concentration of $\mathrm{NH}_{4}{ }^{+}$. If this is acceptable to the local community, it has clear advantages in terms of sanitation, as well as providing an additional source of available $\mathrm{N}$ [40].

\subsection{Availability of nutrients from bios/urries compared to composts and fresh organic wastes}

When compared directly with composting, anaerobic digestion similarly allows an increase over application of fresh wastes in the materials that can be used to fertilize crops. Losses during the treatment process are generally lower during anaerobic digestion than during composting; for example, Thomsen [112] observed losses from composted materials to be $46 \%$ of its total $N$ after 86 days storage, whereas the same material lost less than half this amount during anaerobic digestion, with losses of only $18 \%$. The closed reactor vessel will also eliminate losses of $\mathrm{N}$ or $\mathrm{P}$ by leaching that can occur if the heap is uncovered during composting. Instead of providing a slow release fertilizer that is applied at the start of the season, anaerobic digestion provides a source of immediately available nutrients that should be applied as required by the crops. The liquid component of the bioslurry can be used very much like an inorganic fertilizer, applying it as the crop needs it, but 
avoiding application during periods of heavy rainfall to avoid leaching losses. Digestate application phytotoxic reactions [115-117] related to high $\mathrm{NH}_{4}{ }^{-} \mathrm{N}$ and organic acid concentrations [115,117,118] Although the concentration of $\mathrm{NH}_{4}{ }^{+} \mathrm{N}$ is likely to be lower in the nutrient limited digestates of SSA, care should be taken to avoid too rapid a throughput of organic wastes to avoid high organic acid concentrations. The concentration of volatile fatty acids has also been shown to stimulate immobilization of available nutrients, these compounds acting as a highly decomposable $\mathrm{C}$ source and requiring nutrients for the decomposition [119]. Bioslurry should be applied little and often, and if possible incorporated into the soil to avoid losses of $N$ by volatilization in hot weather [120]. Losses of nutrients from application of bioslurry depend on the management practices chosen by the farmer. If the bioslurry is applied as the crop needs it, losses could potentially be very low. However, if the farmer applies the bioslurry just once, at the start of the season, the losses would be more comparable to those expected from applying fresh organic wastes. If a farmer prefers to apply the organic fertilizer just once, before sowing, a better approach to avoid excessive nutrient losses would be to compost the bioslurry with further $\mathrm{C}$ rich material, a practice that is often used to provide additional composted material in Ethiopia [6], although the potential for enhanced losses of ammonia by volatilisation during composting of bioslurry treated organic waste requires further study.

\section{Biochar produced by pyrolysis}

\subsection{Composition of biochars}

By contrast to composting and anaerobic digestion, which both retain a large proportion of the nutrients in the fresh organic waste, the process of pyrolysis can burn off many of these nutrients, and the biochar that remains can be very deficient in nutrients. The physical and chemical properties of biochar are highly variable, and depend on the feedstock, the availability of oxygen and the temperatures achieved during pyrolysis $[121,122]$. Losses of labile $\mathrm{N}$ on pyrolysis during wildfires can be $70-90 \%[123,124]$, whereas in low temperature pyrolysis, DeLuca et al. [125] suggested that the availability of $P$ can actually be enhanced because $C$ can be lost at temperatures as low as $100^{\circ} \mathrm{C}$, while $P$ loss requires temperatures of $700{ }^{\circ} \mathrm{C}$. Using biochars produced from the same feedstock (chicken manure) at different final pyrolysis temperatures $\left(450\right.$ and $\left.550^{\circ} \mathrm{C}\right)$, Chan et al. [126] suggested that $\mathrm{N}$ and $\mathrm{P}$ concentrations tend to be higher in biochars produced at lower final pyrolysis temperatures. However, low temperature pyrolysis can also produce less stable $\mathrm{C}$ compounds with a lower surface area, so more nutrients may be removed from crop production by immobilization during decomposition of nutrient poor materials or leaching due to limited exchange sites [127-129]. The speed of heating can also impact nutrient availability; Bruun et al. [130] observed that soils amended with biochar produced from wheat straw treated to $525{ }^{\circ} \mathrm{C}$ by slow pyrolysis resulted in net mineralization of $\mathrm{N}$, whereas biochar produced by fast pyrolysis lead to immobilization.

Information on the availability of nutrients in different biochars is essential if we are to understand the potential benefits of biochar to plant growth [131]. In a review of the chemical constituents of biochars produced from a range of different feedstocks under different temperature conditions, Atkinson et al. [49] showed that biochars differ significantly in the ratio of $C$ to nutrients they contain (Fig.1 \& 2), with the presence of the key nutrients being linearly dependent on the levels within the initial feedstocks [132]. The $\mathrm{C}: \mathrm{N}$ ratios observed in the biochars ranged from a minimum of $7: 1$ in biochar produced from sewage sludge at $450{ }^{\circ} \mathrm{C}$ [133], to a maximum of 759:1 in biochar produced from wood (Quercus spp.) at $600{ }^{\circ} \mathrm{C}$ [129]. The C:P ratios of the biochars showed an even larger range, with a minimum of 2:1 in biochar produced from poultry broiler cake at $700{ }^{\circ} \mathrm{C}[134]$ and a maximum of $3400: 1$ in biochar produced from wood (Eucalyptus deglupta) at $350^{\circ} \mathrm{C}[53]$.

\section{Insert Figures 1 and 2 here.}

The availability of these nutrients to the crop depends on the recalcitrance of the organic residues produced. Pyrolysis converts much of the $C$ that remains in the residue into a recalcitrant form, so effectively removing the nutrients from the soil/crop system [139]. However, Gundale and DeLuca [131] suggested that biochar can contribute significant amounts of bioavailable $C$ to the soil. Jones et al [140] used ${ }^{14} \mathrm{C}$ measurements to demonstrate that short-term release of $\mathrm{CO}_{2}$ on addition of biochar to soils was attributable to an equal breakdown of organic $C$ and release of inorganic $C$ contained within the biochar. Using black $\mathrm{C}$ derived from forest fires as an analogue for biochar, Nguyen et al 
[141] attempted to follow longer term dynamics of decomposition in soils from Western Kenya over a 100 year chronosequence following burning. The results suggest that rapid changes in the $\mathrm{C}$ content of black $\mathrm{C}$ derived from wildfires might occur over the first 30 years due to decomposition as well as transport processes. This resulted in mean residence times of only 8.3 years. After 30 years, most of the decomposable material had gone and decomposition rates fell to below detection levels. Although black $\mathrm{C}$ derived from wildfires may differ from biochar due to insufficiently low oxygen-conditions, these results suggest that some methods used to produce biochar may also contribute bioavailable $\mathrm{C}$ to the soil.

Collated $\mathrm{C}: \mathrm{N}$ ratios of biochars, summarized in Fig. 1, suggest that if the decomposable component has the nutrient concentration measured for the total biochar, biochars derived from sewage sludges and poultry manures are likely to mineralize $\mathrm{N}$ whereas biochars derived from plant and wood wastes are likely to strongly immobilize $\mathrm{N}$. The $\mathrm{C}: \mathrm{P}$ ratios of biochars shown in Fig. 2 suggest that decomposing biochars derived from poultry manures, sewage sludge and some types of wood are likely to mineralize P; whereas biochars derived from plant and other wood wastes are likely to strongly immobilize P. However, experiments in Western Kenya, on maize yield response to NPK fertilizers with addition of biochar derived from wood, showed a net increase in $\mathrm{N}$ availability rather than the immobilization of $\mathrm{N}$ suggested by the above C:N ratios [142]. This was attributed to the effects of biochar on nutrient retention through improved cation exchange capacity $[44,143,144]$, but may also be due to uneven distribution of nutrients in the decomposable and recalcitrant portions of the biochar. In a review of biochars from different sources, Spokas et al. [145] noted that the agronomic impacts of biochar additions to degraded soils can be negligible or even negative, but that hardwood biochars produced by traditional methods (kilns or soil pits) provide the most consistent yield increases. In trials in Uganda, biochar produced in a downdraft gasifier from either wood or maize cobs provided higher yields than unamended soils or soils amended with kiln-produced biochars [146].

\subsection{Biochars in Sub-Saharan Africa}

Feedstocks available for use in pyrolysis cook-stoves in SSA depend on the age of the farm as well as the location. Torres-Rojas et al. [147] observed in Western Kenya that farms under 20 years cultivation have a lower proportion of wood biomass available for pyrolysis (45\%) than older farms (70\%). A major proportion of the standing biomass on younger farms is derived from maize residues (cobs $8 \%$ and stover $44 \%$ ). Whereas in older farms the availability of maize residues was decreased by a half. Banana residues contributes $18 \%$ of the material available for pyrolysis in older farms, compared to only $5 \%$ in the younger farms. This would suggest that the biochars produced on the older farms have more potential to boost crop yields, whereas the impacts of the biochars from younger farms will be more variable. In a review of different production processes, Schimmelpfennig and Glaser [148] identified the characteristics of biochars suitable for soil amendment; O/C ratio $<0.4$, $\mathrm{H} / \mathrm{C}$ ratio $<0.6$, black $\mathrm{C}>15 \% \mathrm{C}$, polyaromatic hydrocarbons lower than soil background values, and a surface area $>100 \mathrm{~m}^{2} \mathrm{~g}^{-1}$.

\subsection{Availability of nutrients following application of biochar}

Different feedstocks are suitable for treatment in pyrolysis cook-stoves or biogas digesters; whereas anaerobic digestion uses moist, nutrient rich materials, such as manures, supplemented with inputs of more C-rich materials to bring the $\mathrm{C}: \mathrm{N}$ ratio to the optimum for decomposition, pyrolysis cook-stoves are better fueled using the drier, C-rich materials such as grasses, crop residues and woody biomass [147]. Therefore, direct comparison of the nutrients available following treatment by pyrolysis and anaerobic digestion is not meaningful because the pyrolysis cook-stove uses a different component of the available wastes. If a direct comparison were made, because of the high temperatures used in pyrolysis, a lower proportion of the nutrients in the feedstock would be retained during pyrolysis than during anaerobic digestion. However, addition of biochar to the soil can have an important impact on availability of nutrients from the other sources by reducing losses of soil nutrients by leaching. Loss of water molecules due to the dehydroxylation of the organic waste that occurs during pyrolysis results in the formation of micro-pores. This increases the porosity and surface area of the material, which has been observed by Bargreev et al. [149] to result in a three-fold increase in the surface area, and in some cases can be significantly greater than the surface area of the clay minerals in the soil [150]. The increase in surface area is highly dependent on the final temperature of pyrolysis; low temperature processes potentially allowing volatile organic compounds to recondense, blocking the 
653

654

655

656

657

658

659

660

661

662

663

664

665

666

667

668

669

670

671

672

673

674

675

676

677

678

679

680

681

682

683

684

685

686

687

688

689

690

691

692

693

694

695

696

697

698

699

700

701

702

703

704

705

706

707

708

709

710

711

712

pores and reducing their adsorption potential [127,128]. Both anionic and cationic forms of soil nutrients may be held on exchange sites on the surfaces of the biochar, making them less susceptible to loss by leaching, but remaining accessible to the growing plant [144]. This can improve fertility in soils that are otherwise deficient in exchange sites [50]. Biochars can further improve fertility by raising the soil pH [151]. Mukherjee et al. [152] suggested that the volatile component of the biochar carries its acidity, negative charge, and thus, complexation ability, and so lower temperature biochars produced from the same feedstock are better used to increase soil cation exchange capacity while high temperature biochars tend to raise the $\mathrm{pH}$ of the soil.

\section{The potential of biogas digesters to improve soil fertility and crop production in Sub-Saharan Africa}

The potential for biogas digesters to improve soil fertility and crop production in SSA depends on the types of organic wastes available, the weather conditions at the farm, and management preferences of the farmer.

Application of untreated animal manures is widely practiced in SSA because the high $\mathrm{NH}_{4}{ }^{+}$content results in an initial flush in crop growth that can easily be recognized by the farmer. However, C-rich organic wastes cannot be used in this way, because the decomposition of the organic waste in the soil is likely to lock-up significant amounts of soil nutrients, causing nutrient deficiencies in the crop $[22,27]$. If a high proportion of crop residues and other C-rich organic wastes are available, limiting applications to untreated wastes will omit a potentially important source of organic matter and nutrients from the crop management. Furthermore, because it is recommended that fresh organic wastes are applied some time before sowing to avoid reduced yields due to phytotoxicity [78], if the local weather and soil conditions promote high leaching or volatilization, the risks of losing nutrients before the crop can access them are increased by applying untreated organic wastes in this way.

Treatment of organic wastes before application by anaerobic digestion or composting, allows losses of nutrients to be reduced, and allows C-rich organic wastes to be included in crop nutrition that could not otherwise be used. Bioslurries from anaerobic digestion also provide a high input of immediately available nutrients that promotes a rapid response from the crop [91], but because $C$ rich materials have been decomposed before they are added to the soil, the risks of immobilization are reduced compared to untreated wastes $[95,96]$. Phytotoxicity is also reduced by the digestion process, so the bioslurry can usually be applied directly to the crop when nutrients are needed, greatly reducing the risks of nutrient loss by leaching or volatilization.

Use of bioslurries has the potential to greatly improve the availability of nutrients to the crop, but repeated small applications to avoid volatilization or leaching losses require a higher input of labor than a single dose of organic fertilizer at the start of the season. In composts, nutrients are provided in a rapidly released form that will gradually become available to the crop over the course of the growing season, so much reducing the risks of nutrient loss, but without the additional labor requirement [56]. Losses during treatment from composting are approximately double the losses that occur during anaerobic digestion [112], but if the farmer prefers to apply organic fertilizer just once at the start of the season, the risks of nutrient loss by leaching or volatilization will be much reduced by using composts instead of using bioslurries.

A larger proportion of $\mathrm{N}$ is likely to be lost during pyrolysis than during anaerobic digestion or composting [123,124], but incorporation of biochar into the soil can save native soil nutrients from loss, so increasing the overall availability of nutrients from the soil $[44,143,144]$. Crop yield and crop yield stability (regularity of achieving a good yield) have been shown to be related to soil organic matter content [16]; the higher the organic matter content of the soil, the higher the crop yield and the more stable the inter-annual variability of yield. Lal [20] has also argued that soil organic matter can underpin global food security, and its role in Africa in supporting soil fertility and food production has been confirmed [20]. Application of treated and untreated organic wastes to crops not only supplies nutrients, but also changes the organic matter content of the soil, which will go on to further impact crop productivity. Pyrolysis of organic wastes has been shown to be the treatment with the highest potential to sequester $C$ in the soil [153], although composting also sequesters more $C$ than application of untreated wastes [154].

So what method of organic waste treatment should a farmer use to improve soil fertility and crop 
production? Bioslurry and compost both provide an improved supply of nutrients to crops over using untreated organic wastes. Pyrolysis reduces the $\mathrm{N}$ content of the organic waste, but application of biochar can provide exchange sites to the soil, and so acts as a soil improver. Anaerobic digestion and pyrolysis both provide convenient sources of household energy. Therefore, if sufficient water is available for anaerobic digestion [40], organic wastes should ideally be combined to adjust the $\mathrm{C} / \mathrm{N}$ ratio to around 25 [92,155], producing an optimum return of biogas and an efficient use of the nutrients in the organic wastes to improve crop production. This can be applied directly as the crop needs it, but if the farmer prefers a single application before sowing, the bioslurry should be mixed with more $\mathrm{C}$ rich organic waste to produce a compost that can be applied at the start of the season without risking high nutrient losses. Any remaining $C$ rich organic wastes should be burnt in a pyrolysis cook-stove and the biochar used as a soil improver. In this way, a steady improvement in the soil condition will be achieved and more efficient use will be made of the nutrients applied in the bioslurry or compost.

\section{Acknowledgements}

We are very grateful to the UK Department for International Development (DFID) New and Emerging Technologies Research Call for funding this work. PS is a Royal Society-Wolfson Research Merit Award holder.

\section{REFERENCES}

[1] United Nations, World Population Prospect: The 2012 Revision. Data Sources and Meta Information. New York:Department of Economic and Social Affairs, Population Division;2013. Available online at: http://esa.un.org/unpd/wpp/sources/country.aspx and http://esa.un.org/unpd/wpp/Excel-Data/WPP2012_F02_METAINFO.xls

[2] FAO. Investing in Agriculture for Economic Growth and Food Security. Report prepared for the African Union (AU) Heads of State and Government Summit in Sirte, Libya, July 2009.

[3] Conceição P, Fuentes-Nieva R, Horn-Phathanothai L, Ngororano A. Food security and human development in Africa: Strategic considerations and directions for further research. African Development Review 2011;23:237-46.

[4] Smith P, Martino D, Cai Z, Gwary D, Janzen H, Kumar P, et al. Policy and technological constraints to implementation of greenhouse gas mitigation options in agriculture. Agr Ecosyst Environ 2007;118:6-28.

[5] Tilman D, Balzer C, Hill J, Befort BL. Global food demand and the sustainable intensification of agriculture. P Natl Acad Sci USA 2011;108:20260-4.

[6] Smith JU, Austin G, Avery L, Balana B, Bechtel K, Casson E, et al. The Potential of Small-Scale Biogas Digesters to Alleviate Poverty and Improve Long Term Sustainability of Ecosystem Services in Sub-Saharan Africa. DFID NET-RC A06502. Final report.http://www.dfid.gov.uk/r4d/SearchResearchDatabase.asp?OutputID=187175. Accessed 10/12/2011.

[7] Troschinetz AM, Mihelcic JR. Sustainable recycling of municipal solid waste in developing countries. Waste Manage 2009;29:915-23.

[8] Couth R, Trois C. Carbon emissions reduction strategies in Africa from improved waste management: A review. Waste Manage 2010;30:2336-46.

[9] Mihelcic JR, Fry LM, Shaw R. Global potential of phosphorus recovery from human urine and feces. Chemosphere 2011;84:832-9.

[10] Russell EJ. Russell's soil conditions and plant growth. In: Wild A, editor, Harlow, Essex: Longman scientific and technical; 1988.

[11] Williams CN, Joseph KT. Climate, soil and crop production in the humid tropics. Revised edition, third Impression, Oxford: Oxford University Press; 1976.

[12] Vanlauwe B, Kihara J, Chivenge P, Pypers P, Coe R, Six J. Agronomic use efficiency of N fertilizer in maize-based systems in sub-Saharan Africa within the context of integrated soil fertility management. Plant Soil 2011; 339:35-50.

[13] Bationo A, Mokwunye AU. Alleviating soil fertility constraints to increased crop production in West Africa: The experience in the Sahel. Fert Res 1991;29:95-115.

[14] Bationo A, Mokwunye AU. Role of manures and crop residue in alleviating soil fertility constraints to crop production: With special reference to the Sahelian and Sudanian zones of 
West Africa. Fert Res 1991;29:117-25.

[15] Assefa Abegaz. Indigenous soil nutrient supply and effects of fertilizer application on yield, N, P and $\mathrm{K}$ uptake, recovery and use efficiency of barley in three soils of Teghane, the Northern Highlands of Ethiopia. Afr J Agr Res 2008;3:686-97.

[16] Pan G, Smith P, Pan W. The role of soil organic matter in maintaining the productivity and yield stability of cereals in China. Agriculture, Ecosystems and Environment 2009;129:344-8.

[17] Bessam F, Mrabet R. Long-term changes in soil organic matter under conventional tillage and no-tillage systems in semiarid Morocco. Soil Use Manage 2003;19:139-43.

[18] De Ridder $\mathrm{N}$, van Keulen $\mathrm{H}$. Some aspects of the role of organic matter in sustainable intensified arable farming systems in the West-African semi-arid tropics (SAT). Fert Res 1990;26:299-310.

[19] Chivenge P, Vanlauwe B, Six J. Does the combined application of organic and mineral nutrient sources influence maize productivity? A meta-analysis. Plant Soil 2011;342:1-30.

[20] Lal R, Soil carbon sequestration impacts on global climate change and food security. Science 2004;303:1623-7.

[21] Aune JA, Lal R, Agricultural productivity in the tropics and critical limits of properties of Oxisols, Ultisols, and Alfisols. Trop Agr 1997;74:96-103.

[22] Nyamangara J, Piha MI, Giller KE. Effects of combined cattle manure and mineral nitrogen on maize N uptake and grain yield. Afr Crop Sci J 2003;11:289-300.

[23] Yamoah CF, Bationo A, Shapiro B, Koala S. Trend and stability analyses of millet yields treated with fertilizer and crop residues in the Sahel. Field Crop Res 2002;75:53-62.

[24] Sanchez PA. Ecology - Soil fertility and hunger in Africa. Science 2002;295:2019-20.

[25] Janssen BH. Simple models and concepts as tools for the study of sustained soil productivity in long-term experiments. I. New soil organic matter and residual effect of $P$ from fertilizers and farmyard manure in Kabete, Kenya. Plant Soil 2011;339:3-16.

[26] World Bank. World Development Report 2008: Agriculture for Development, World Bank, Washington DC; 2008.

[27] Ma BL, Dwyer LM, Gregorich EG. Soil nitrogen amendment effects on nitrogen uptake and grain yield of maize. Agron J 1999;91:650-6.

[28] Molden D. Accounting for Water Use and Productivity. SWIM Paper 1. International Irrigation Management Institute, Colombo, Sri Lanka 1997

[29] Brady NC, Weil RR. The Nature and Properties of Soil. 14th Edition. New York: Prentice Hall; 2007.

[30] Bates BC, Kundzewicz ZW, Wu S, Palutikof JP. Climate change and water. Technical Paper of the Intergovernmental Panel on Climate Change, Geneva: IPCC Secretariat; 2008.

[31] Alcamo J, van Vuuren D, Ringler C, Cramer W, Matsui T, Alder J, Schulze K. Changes in nature's balance sheet: model-based estimates of future worldwide ecosystem services. Ecol Soc 2005;10:19.

[32] Bruinsma J (editor). World Agriculture: Towards 2015/2030, An FAO Perspective. Earthscan and Food and Agriculture Organization, London and Rome; 2003.

[33] Falkenmark M, Rockström J. Balancing Water for Humans and Nature: The New Approach in Ecohydrology. Earthscan, London 2004.

[34] Rosegrant M, Cai X., Cline S. World Water and Food to 2025. Dealing with Scarcity. International Food Policy Research Institute, Washington, D.C. 2002.

[35] Rosegrant MW, Cline SA., Li W, Sulser TB, Valmonte-Santos RA. Looking Ahead. Long Term Prospects for Africa's Agricultural Development and Food Security. 2020 Discussion paper 41. International Food Policy Research Institute, 2020 Vision for Food, Agriculture and the Environment, Washington, D.C. 2005.

[36] Seckler D, Amarasinghe U, Molden D, de Silva R, Barker R. World Water and Demand and Supply, 1990 to 2025: Scenarios and Issues. Research Report 19. International Water Management Institute, Colombo 1998.

[37] Shiklomanov IA. Appraisal and assessment of world water resources. Water Int 2000;25:11-32.

[38] Vörösmarty CJ, Lettenmaier D, Leveque C, Meybeck M, Pahl-Wostl C, Alcamo J, et al. Humans transforming the global water system. EOS, Transactions, American Geophysical Union 2004;85:509-14.

[39] Parawira W. Biogas technology in sub-Saharan Africa: status, prospects and constraints. Rev Environ Sci Biotechnol 2009;8:187-200.

[40] Orskov RE, Yongabi KA, Subedi M, Smith J. Holistic Application of Biogas for Small Scale Farmers in Africa and Asia. Biomass Bioenergy 2012 (this issue).

[41] Openshaw K. Estimating biomass supply:focus on Africa. In: IEA Proceedings Biomass 
Energy:data, analysis and trends, March 23-24; Paris. IEA/OECD;1998. p. 241-55.

[42] Mapfumo P, Giller KE. Soil Fertility Management Strategies and Practices by Smallholder Farmers in Semi-arid Areas of Zimbabwe. Patancheru, AP, India. ICRISAT/FAO;2001.

[43] Eaton D, Hilhorst T. Opportunities for managing solid waste flows in the periurban interface of Bamako and Ouagadougou. Environ Urban 2003;15:53-63.

[44] Lewcock C. Farmer use of urban waste in Kano. Habitat Int 1995;19:225-34.

[45] Baijukya FP, de Ridder N, Masuki KF, Giller KE. Dynamics of banana-based farming systems in Bukoba District, Tanzania: changes in land use, cropping and cattle keeping. Agric Ecosyst Environ 2005;106:395-406.

[46] Graber ER, Hadas E. Potential energy generation and carbon savings from waste biomass pyrolysis in Israel. Ann Environ Sci 2009;3:207-16.

[47] Mohan D, Pittman CU, Steele PH. Pyrolysis of wood/biomass for bio-oil: a critical review. Energ Fuel 2006; 20:848-89.

[48] Preston CM, Schmidt MWI. Black (pyrogenic) carbon: a synthesis of current knowledge and uncertainties with special consideration of boreal regions. Biogeosciences 2006;3:397-420.

[49] Atkinson CJ, Fitzgerald JD, Hipps NA. Potential mechanisms for achieving agricultural benefits from biochar application to temperate soils: a review. Plant Soil 2010;337:1-18.

[50] Lehmann J, da Silva Jr JP, Steiner C, Nehls T, Zech W, Glaser B. Nutrient availability and leaching in an archaeological Anthrosol and Ferralsol of the Central Amazon basin: fertilizer, manure and charcoal amendments. Plant Soil 2003;249:343-57.

[51] Yamato M, Okimori Y, Wibowo IF, Anshori S, Ogawa M. Effects of the application of charred bark in Acacia mangium on the yield of maize, cowpea, peanut and soil chemical properties in south Sumatra, Indonesia. Soil Sci Plant Nutr 2006;52:489-95.

[52] Steiner C, Teixeira WG, Lehmann J, Nehls T, de Macedo JLV, Blum WEH, et al. Long term effects of manure, charcoal and mineral fertilization on crop production and fertility on a highly weathered Central Amazonian upland soil. Plant Soil 2007;291:275-90.

[53] Rondon MA, Lehmann J, Ramirez J, Hurtado M. Biological nitrogen fixation by common beans (Phaseolus vulgaris L) increases with bio-char additions. Biol Fert Soils 2007;43:699-708.

[54] Asai H, Samson BK, Stephan HM, Songyikhangsuthor K, Inoue Y, Shiraiwa T, Horie T. Biochar amendment techniques for upland rice production in Northern Laos: soil physical properties, leaf SPAD and grain yield. Field Crop Res 2009;111:81-4.

[55] Zhang Y, Lashermes G, Houot S, Doublet J, Steyer JP, Zhu YG, et al. Modelling of organic matter dynamics during the composting process. Waste Manage 2012:32;19-30.

[56] Kirchmann H, Witter E. Composition of fresh, aerobic and anaerobic farm animal dungs. Bioresource Technol 1992;40:137-42.

[57] Ryan MC, Graham GR, Rudolph DL. Contrasting nitrate adsorption in Andisols of two coffee plantations in Costa Rica. J Environ Qual 2001;30:1848-52.

[58] Van Ranst A, Shamshuddin J, Baert G, Dzwowa PK. Charge characteristics in relation to free iron and organic matter of soils from Bambouto Mountains, Western Cameroon. Eur J Soil Sci 1998;49:243-252.

[59] Catt JA, Howse KR, Christian, DG, Lane PW, Harris GL, Goss MJ. Strategies to decrease nitrate leaching in the Brimstone Farm Experiment, Oxfordshire, UK, 1988-93: the effect of straw incorporation. J Agr Sci 1998;131:309-19.

[60] Jiang X, Maa Y, Yuan J, Wright AL, Li H. Soil particle surface electrochemical property effects on abundance of ammonia-oxidizing bacteria and ammonia-oxidizing archaea, $\mathrm{NH}_{4}{ }^{+}$activity, and net nitrification in an acid soil. Soil Biol Biochem 2011;43:2215-21.

[61] Bradbury NJ, Whitmore AP, Hart PBS, Jenkinson DS. Modelling the fate of nitrogen in crop and soil in the years following application of ${ }^{15} \mathrm{~N}$-labelled fertilizer to winter wheat. J Agr Sci 1993;121:363-79.

[62] Smith J, Coleman K, Gottschalk P, Bellarby J, Richards M, Nayak D, et al. Estimating changes in national soil carbon stocks using ECOSSE - a new model that includes upland organic soils. Part I. Model description and uncertainty in national scale simulations of Scotland. Climate Res 2010;45:179-92.

[63] Jenkinson DS, Hart PBS, Rayner JH, Parry LC. Modelling the turnover of organic matter in long-term experiments at Rothamsted. INTECOL Bull 1987;15:1-8.

[64] Stanford G, Epstein E. Nitrogen mineralization-water relations in soils. Soil Sci Soc Am J 1974;38:103-7.

[65] Leifeld J, Zimmermann M, Fuhrer J. Simulating decomposition of labile soil organic carbon: Effects of pH. Soil Biol Biochem 2008;40:2948-51.

[66] Setia R, Marschner P, Baldock J, Chittleborough D, Smith P, Smith J. Salinity effects on carbon 
mineralization in soils of varying texture. Soil Biol Biochem 2011:43;667-74.

[67] Coleman K, Jenkinson DS. RothC-26.3. A model for the turnover of carbon in soil. In: Powlson DS, Smith P, Smith JU, editors. Evaluation of soil organic matter models using existing longterm datasets. NATO ASI Series I, Vol 38. Springer, Berlin; 1996, p. 237-46.

[68] Wattiaux MA, Karg KL. Protein level for alfalfa and corn silage-based diets: II. Nitrogen balance and manure characteristics. J Dairy Sci 2004;87:3492-502.

[69] Krogdahl Å, Dahlsgård B. Estimation of nitrogen digestibility in poultry: Content and distribution of major urinary nitrogen compounds in excreta. Poultry Sci 1981;60:2480-85.

[70] Schefferle HE. The decomposition of uric acid in built up poultry litter. J Appl Microbiol $1965 ; 28: 412-420$.

[71] van Vuuren AM, Meijs JAC. Effects of herbage composition and supplement feeding on the excretion of nitrogen in dung and urine by grazing dairy cows. In van der Meet HG et al., editors. Animal Manure on Grassland and Fodder Crops. Fertilizer or Waste? Dordrecht: Martinus Nijhoff Publishers; 1987, p. 17-26.

[72] Salcedo G, Martínez-Suller L, Arriaga H, Merino P. Effects of forage supplements on milk production and chemical properties, in vivo digestibility, rumen fermentation and $\mathrm{N}$ excretion in dairy cows offered red clover silage and corn silage or dry ground corn. Irish Journal of Agricultural and Food Research 2010;49:115-128.

[73] Tisdale SL, Nelson WL, Beaton JD. Soil fertility and fertilizers, New York. Macmillan, 1985, p. 161-168.

[74] Eghball B. Leaching of phosphorus fractions following manure or compost application. Commun Soil Sci Plan 2003;34:2803-15.

[75] Sharpley AN, Moyer B. Phosphorus forms in manure and compost and their release during simulated rainfall. J Environ Qual 2000;29:1462-9.

[76] Eghball B, Power JF. Phosphorus and nitrogen-based manure and compost application: corn production and soil phosphorus. Soil Sci Soc Am J 1999;63:895-901.

[77] Möller K, Müller T. Effects of anaerobic digestion on digestate nutrient availability and crop growth: A review. Eng Life Sci 2012;12:242-57.

[78] Bernal MP, Sanchez-Monedero MA, Paredes C, Roig A. Carbon mineralization from organic wastes at different composting stages during their incubation with soil. Agr Ecosyst Environ 1998;69:175-89.

[79] Payet N, Findeling A, Chopart J-L, Feder F, Nicolini E, Saint Macary H, et al. Modelling the fate of nitrogen following pig slurry application on a tropical cropped acid soil on the island of Réunion (France). Agr Ecosyst Environ 2009;134:218-33.

[80] Kaboré TW-T, Houot S, Hien E, Zombré P, Hien V, Masse D. Effect of the raw materials and mixing ratio of composted wastes on the dynamic of organic matter stabilization and nitrogen availability in composts of Sub-Saharan Africa. Bioresource Technol 2010;101:1002-1013.

[81] Paul JW, Beauchamp EG. Nitrogen availability for corn in soils amended with urea cattle slurry, and solid and composted manures. Can J Soil Sci 1993;73: 253-266.

[82] De Bertoldi M, Vallini G, Pera A. The biology of composting: a review. Waste Manag Res 1983;1:157-76.

[83] Beck-Friis B, Smårs S, Jönsson H, Kirchmann H. Gaseous emissions of carbon dioxide, ammonia and nitrous oxide from organic household waste in a compost reactor under different temperature regimes. J Agr Eng Res 2001;78:423-30.

[84] Tyson SC, Cabrera ML. Nitrogen mineralization in soils amended with composted and uncomposted poultry litter. Commun Soil Sci Plan 1993;24:2361-74.

[85] Rufino MC, Rowe EC, Delve RJ, Giller KE. Nitrogen cycling efficiencies through resource-poor African crop-livestock systems. Agr Ecosyst Environ

[86] Kirchmann H, Widén P. Separately collected organic household wastes: chemical composition and composting characteristics. Swed J Agr Res1994;24:3-12.

[87] Eklind Y, Kirchmann H. Composting and storage of organic household waste with different litter amendments. Il: nitrogen turnover and losses. Bioresource Technol 2000;74:125-33.

[88] Beck-Friis B, Pell M, Sonesson U, Jönsson H, Kirchmann H. Formation and emission of $\mathrm{N}_{2} \mathrm{O}$ and $\mathrm{CH}_{4}$ from compost heaps of organic household waste. Environ Monit Assess 2000;62:31731.

[89] IPCC. WGI. Climate Change The Physical Science Basis, Cambridge, UK: Cambridge University Press; 2007.

[90] Martins O, Dewes T. Loss of nitrogenous compounds during composting of animal wastes. Bioresour Technol 1992;42:103-11.

[91] Gutser R, Ebertseder T, Weber A, Schraml M, Schmidhalter U. Short-term and residual 
availability of nitrogen after long-term application of organic fertilizers on arable land. J Plant Nutr Soil Sci 2005;168:439-46.

[92] Schievano A, D'Imporzano G, Salati S, Adani F. On-field study of anaerobic digestion full-scale plants (Part I): An on-field methodology to determine mass, carbon and nutrients balance. Bioresource Technol 2011;102:7737-44.

[93] Loria ER, Sawyer JE. Extractable soil phosphorus and inorganic nitrogen following application of raw and anaerobically digested swine manure. Agron J 2005;97:879-85.

[94] Möller K, Stinner W. Effects of organic wastes digestion for biogas production on mineral nutrient availability of biogas effluents. Nutr Cycl Agroecosys 2010;87:395-413.

[95] Cysneiros D, Banks CJ, Heaven S. Anaerobic digestion of maize in coupled leach-bed and anaerobic filter reactors. Wat Sci Technol 2008;58:1505-11.

[96] Jacobi HF, Moschner CR, Hartung E. Use of near infrared spectroscopy in monitoring of volatile fatty acids in anaerobic digestion. Water Sci Technol 2009;60:339-46.

[97] Bateman EJ, Baggs EM. Contributions of nitrification and denitrification to N2O emissions from soils at different waterfilled pore space. Biol Fert Soils 2005;41:379-88.

[98] Ward AJ, Hobbs PJ, Holliman PJ, Jones DL. Optimization of the anaerobic digestion of agricultural resources. Bioresource Technol 2008;99:7928-40.

[99] Möller K, Schulz R, Müller T. Substrate inputs, nutrient flows and nitrogen loss of two centralized biogas plants in southern Germany. Nutr Cycl Agroecosys 2010;87:307-25.

[100] Field JA, Caldwell JS, Jeyanayagam S, Reneau Jr. RB, Kroontje W, Collins Jr. ER. Fertilizer recovery from anaerobic digesters. T ASAE 1984;27:1871-6.

[101] Larsen KE. Fertilizer value of anaerobic treated cattle and pig slurry to barley and beet. In: Kofoed AD, Williams JH, L'Hermite P, editors. Efficient land use of sludge and manure, London: Elsevier Applied Science Publishers; 1986, p. 56-60.

[102] Messner H, Amberger A. Composition, nitrification and fertilizing effect of anaerobically fermented slurry. In: Szabolcs I, Welte E, editors. Agricultural waste management and environmental protection: 4th International CIEC Symposium, Braunschweig, Germany: International Scientific Centre of Fertilizers (CIEC); 1987, p. 125-130.

[103] Plaixats J, Barcelo J, Garcia-Moreno J. Characterization of the effluent residue from anaerobic digestion of pig excreta for its utilization as fertilizer. Agrochimica 1988;32:236-9.

[104] Strik DPBTB, Domnanovich AM, Zani L, Braun R, Holubar P. Prediction of trace compounds in biogas from anaerobic digestion using the MATLAB Neural Network Toolbox. Environ Modell Softw 2005;20:803-10.

[105] Massé DI, Croteau F, Massé L. The fate of crop nutrients during digestion of swine manure in psychrophilic anaerobic sequencing batch reactors. Bioresource Technol 2007;98:2819-23.

[106] Yadvika S, Sreekrishnan TR, Kohli S, Rana V. Enhancement of biogas production from solid substrates using different techniques - a review. Bioresource Technol 2004;95:1-10.

[107] Boadzo A, Chowdhury SP, Chowdhury S. Modeling and assessment of dairy farm-based biogas plants in South Africa. Power and Energy Society general Meeting, IEEE 2011, doi 10.1109/PES.2011.6039181.

[108] Emmerling Ch, Barton J. Anaerobic co-digestion of topinambour (Helianthus tuberosus L.) and properties of the remaining biogas manure. Arch Agron Soil Sci 2007;53:683-90.

[109] de Boer HC. Co-digestion of animal slurry can increase short-term nitrogen recovery by crops. J Environ Qual 2008:37:1968-73.

[110] Angelidaki I, Ahring BK. Thermophilic anaerobic digestion of livestock waste: the effect of ammonia. Appl Microbiol Biotechnol 1994; 38:560-4.

[111] Idnani MA, Laura RD. Increased production of biogas from cowdung by adding other agricultural waste materials. J Sci Food Agric 1971;22:164-7.

[112] Thomsen IK. C and $\mathrm{N}$ transformations in $15 \mathrm{~N}$ cross-labelled solid ruminant manure during anaerobic and aerobic storage. Bioresour Technol 2000;72:267-74.

[113] Sánchez M, Gomez X, Barriocanal G, Cuetos MJ, Morán A. Assessment of the stability of livestock farm wastes treated by anaerobic digestion. Int Biodeterior Biodegradation 2008;62:421-6.

[114] Gell K, van Groenigen JW, Cayuela ML. Residues of bioenergy production chains as soil amendments: immediate and temporal phytotoxicity. J Hazard Mater 2011;186:2017-25.

[115] Abdullahi YA, Akunna JC, White NA, Hallett PD, Wheatley R. Investigating the effects of anaerobic and aerobic post-treatment on quality and stability of organic fraction of municipal solid waste as soil amendment. Bioresour Technol 2008;99:8631-6.

[116] Poggi-Varaldo HM, Trejo-Espino J, Fernandez-Villagomez G, Esparza-Garcia F, CaffarelMendez S, Rinderknecht-Seijas N. Quality of anaerobic compost from paper mill and municipal 
1013

1014

1015

1016

1017

1018

1019

1020

1021

1022

1023

1024

1025

1026

1027

1028

1029

1030

1031

1032

1033

1034

1035

1036

1037

1038

1039

1040

1041

1042

1043

1044

1045

1046

1047

1048

1049

1050

1051

1052

1053

1054

1055

1056

1057

1058

1059

1060

1061

1062

1063

1064

1065

1066

1067

1068

1069

1070

1071

1072

solid wastes for soil amendment. Water Sci Technol 1999;40:179-86.

[117] Salminen E, Rintala J. Anaerobic digestion of organic solid poultry slaughterhouse waste - a review. Biores Technol 2002;83:13-26.

[118] Drennan MF, DiStefano TD. Characterization of the curing process from high-solids anaerobic digestion. Bioresour Technol. 2010;101:537-544.

[119] Kirchmann $\mathrm{H}$, Lundvall $\mathrm{A}$, Relationship between $\mathrm{N}$ immobilization and volatile fatty acids in soil after application of pig and cattle slurry. Biol Fertil Soils 1993;15:161-4.

[120] Möller K, Stinner W, Deuker A, Leithold G. Effects of different manuring systems with and without biogas digestion on nitrogen cycle and crop yield in mixed organic dairy farming systems. Nutr Cycl Agroecosys 2008;82:209-32.

[121] Lua AC, Yang T. Effects of vacuum pyrolysis conditions on the characteristics of activated carbons derived from pistachio-nut shells. J Colloid Interf Sci 2004;276:364-72

[122] Gundale MJ, DeLuca TH. Temperature and source material influence ecological attributes of ponderosa pine and Douglas-fir charcoal. Forest Ecol Manag 2006;231:86-93.

[123] Raison RJ. Modification of the soil environment by vegetation fires, with particular reference to nitrogen transformations: a review. Plant Soil 1979;51:73-108.

[124] Rovira P, Duguy B, Vallejo VR. Black carbon in wildfire-affected shrubland Mediterranean soils. J Plant Nutr Soil Sc 2009;172:43-52.

[125] DeLuca TH, MacKenzie MD, Gundale MJ Holben WE. Wildfire-produced charcoal directly influences nitrogen cycling in Ponderosa pine forests. Soil Sci Soc Am J 2006;70:448-53.

[126] Chan KY, Van Zwieten L, Meszaros I, Downie A, Joseph S. Using poultry litter biochars as soil amendments. Aust J Soil Res 2008;46:437-44.

[127] Kwon S, Pignatello JJ. Effects of natural organic substances on the surface and adsorptive properties of environmental black carbon (char): pseudo pore blockage by model lipid components and its implications for $\mathrm{N}_{2}$-probed surface properties of natural sorbents. Environ Sci Technol 2005;39:7932-9.

[128] Pignatello JJ, Kwon S, Lu Y. Effects of natural organic substances on the surface and adsorptive properties of environmental black carbon (char): attenuation of surface activity by humic and fulvic acids. Environ Sci Technol 2006;40:7757-63.

[129] Nguyen BT, Lehmann J. Black carbon decomposition under varying water regimes. Org Geochem 2009;40:846-53.

[130] Bruun EW, Ambus P, Egsgaard H, Hauggaard-Nielsen, H. Effects of slow and fast pyrolysis biochar on soil $\mathrm{C}$ and $\mathrm{N}$ turnover dynamics. Soil Biol Biochem 2012;46:73-9.

[131] Gundale MJ, DeLuca TH. Charcoal effects on soil solution chemistry and growth of Koeleria macrantha in the ponderosa pine/Douglas-fir ecosystem. Biol Fert Soils 2007;43:303-11.

[132] Alexis MA, Rasse DP, Rumpel C, Bardoux G, Pechot N, Schmalzer P, Drake B, Mariotti A. Fire impact on $\mathrm{C}$ and $\mathrm{N}$ losses and charcoal production in a scrub oak ecosystem. Biogeochemistry 2007;82:201-16.

[133] Bridle TR, Pritchard D. Energy and nutrient recovery from sewage sludge via pyrolysis. Water Sci Technol 2004;50:169-75.

[134] Lima IM, Marshall WE. Granular activated carbons from broiler manure: physical, chemical and adsorptive properties. Bioresource Technol 2005;96:699-706.

[135] Tsai WT, Lee MK, Chang YM. Fast pyrolysis of rice straw, sugarcane bagasse and coconut shell in an induction-heating reactor. J Anal Appl Pyrol 2006;76:230-7.

[136] Magrini-Bair KA, Czernik S, Pilath HM, Evans RJ, Maness PC, Leventhal J. Biomass derived, carbon sequestration, designed fertilizers. Ann Environ Sci 2009;3:217-25.

[137] Novak JM, Busscher WJ, Laird DL, Ahmedna M, Watts DW, Niandou MAS. Impact of biochar amendment on fertility of a Southeastern coastal plain soil. Soil Sci 2009;174:105-12.

[138] Busscher WJ, Novak JM, Evans DE, Watts DW, Niandou MAS, Ahmedna M. Influence of pecan biochar on physical properties of Norfolk loamy sand. Soil Sci 2010;175:10-44.

[139] Chan KY, Xu Z. Biochar: nutrient properties and their enhancement. Chapter 5. In: Lehmann J, Joseph S, editors. Biochar for environmental management science and technology, London. Earthscan; 2009, p. 67-84.

[140] Jones DL, Murphy DV, Khalid M, Ahmadd W, Edwards-Jones G, DeLuca TH. Short-term biochar-induced increase in soil $\mathrm{CO}_{2}$ release is both biotically and abiotically mediated. Soil Biol Biochem 2011;43:1723-31.

[141] Nguyen BT, Lehmann J, Kinyangi J, Smernik R, Riha SJ, Engelhard MH. Long-term black carbon dynamics in cultivated soil. Biogeochem, 2008;89:295-308.

[142] Kimetu JM, Lehmann J, Ngoze SO, Mugendi DN, Kinyangi JM, Riha S, Verchot L, Recha JW, Pell AN. Reversibility of soil productivity decline with organic matter of differing quality along a 
degradation gradient. Ecosystems 2008;11:726-39.

[143] Glaser B, Parr M, Braun C, KopoloG. Biochar is carbon negative Nature Geoscience 2002;2:2.

[144] Liang B, Lehmann J, Solomon D, Kinyangi J, Grossman J, O'Neill B, et al. Black carbon increases cation exchange capacity in soils. Soil Sci Soc Am J 2006;70:1719-30.

[145] Spokas KA, Cantrell KB, Novak JM, Archer DW, Ippolito JA, Collins HP et al. Biochar: A Synthesis of its agronomic impact beyond carbon sequestration. J Environ Qual 2012;41: 97389.

[146] Deal C, Brewer CE, Brown RC, Okure MAE, Amoding A. Comparison of kiln-derived and gasifier-derived biochars as soil amendments in the humid tropics. Biomass Bioenerg 2012;161-8.

[147] Torres-Rojas D, Lehmann J, Hobbs P, Joseph S, Neufeldt H. Biomass availability, energy consumption and biochar production in rural households of Western Kenya. Biomass Bioenerg 2011;3537-46.

[148] Schimmelpfennig S, Glaser B. One step forward toward characterization: some important material properties to distinguish biochars. J Environ Qual 2012;41:1001-13.

[149] Bargreev A, Bandosz TJ, Locke DC. Pore structure and surface chemistry of adsorbents obtained by pyrolysis of sewage sludge-derived fertilizer. Carbon 2001;39:1971-9.

[150] Downie A, Crosky A, Munroe P. Physical properties of biochar. Chapter 2. In: Lehmann J, Joseph S, editors. Biochar for environmental management science and technology, London. Earthscan; 2009, p.13-32.

[151] Xu R-K, Zhao A-Z, Yuan J-H, Jiang J. pH buffering capacity of acid soils from tropical land subtropical regions of China as influenced by incorporation of crop straw biochars. J Soils Sediments 2012;12:494-502.

[152] Mukherjee A, Zimmerman AR, Harris W. Surface chemistry variations among a series of laboratory-produced biochars. Geoderma 2011;163:247-55.

[153] Smith J, Abegaz A, Matthews R, Subedi M, Orskov R, Tumwesige V, et al. What is the potential for biogas digesters to improve soil carbon sequestration in Sub-Saharan Africa? Biomass Bioenergy 2012 (this issue).

[154] Kirchmann H, Bernal MP. Organic waste treatment and C stabilization efficiency. Soil Biol Biochem 1997;29:1747-53.

[155] Khalid A, Arshad M, Anjum M, Mahmood T, Dawson L. The anaerobic digestion of solid organic waste. Waste Manage 2011;31:1737-44. 


\section{Figures}

1107

1108

1109

1110

1111

1112

Fig. 1 - The carbon to nitrogen mass ratios of biochar derived from a range of different feedstocks (collated from $[50,51,53,125,126,129,133,134,135,136,137,138])$.

Fig. 2 - The carbon to phosphorus mass ratios of biochar derived from a range of different feedstocks (collated from $[50,51,53,125,126,129,133,134,135,136,137,138]$ ). 
1113 Fig. 1

1114

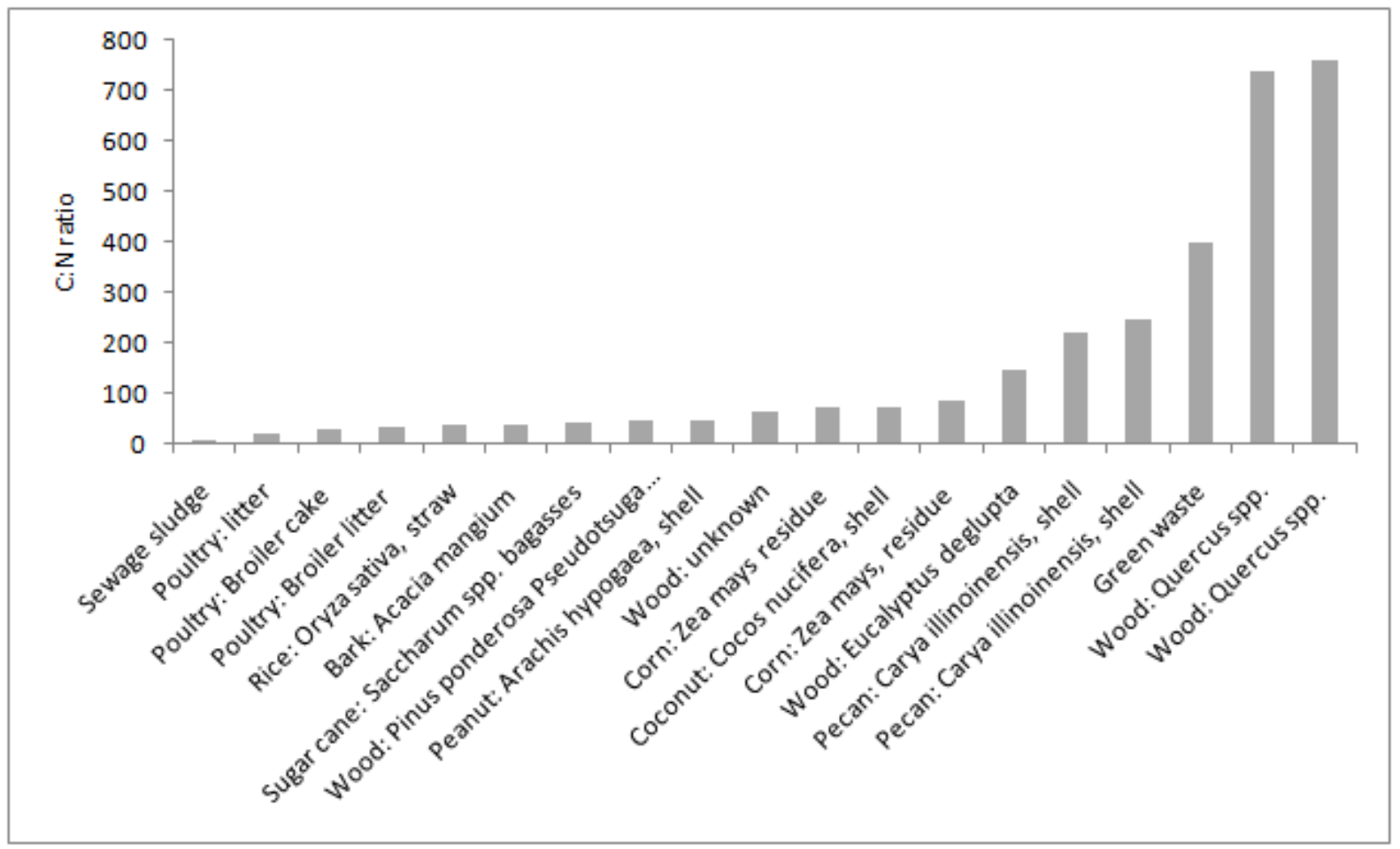

1115

1116 
1117 Fig. 2

1118

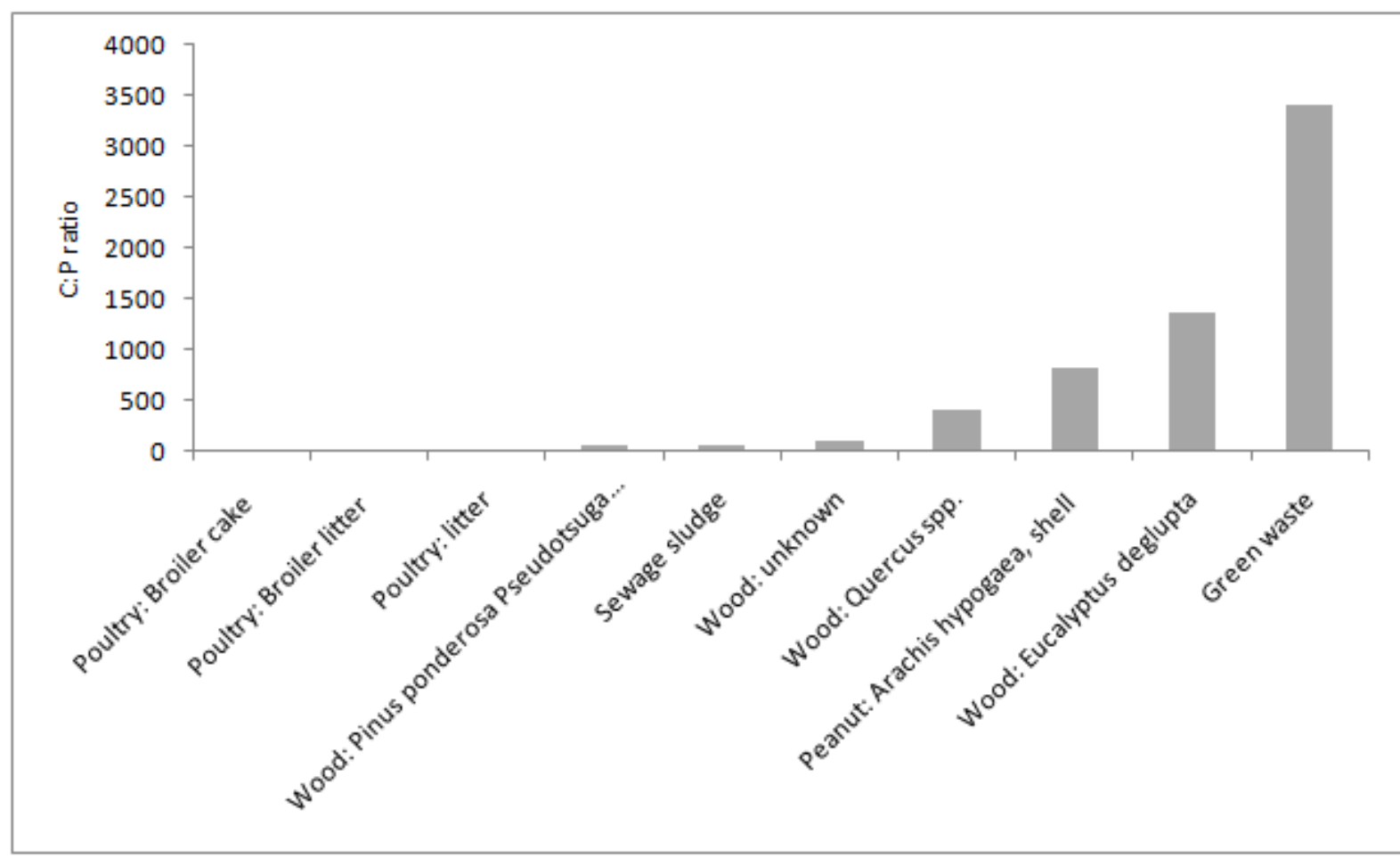

1120 
1121

1122

1123

1124

1125

1126

1127

1128

\section{Highlights}

- Application of bioslurry from biogas digesters is compared to other uses

- Bioslurry / composts tend to provide more nutrients than untreated wastes / biochar

- Bioslurry provides nutrients in a highly available form

- To avoid high losses, bioslurry should be applied as the crop requires nutrients

- Composts can be applied at the start of the growing season without nutrient loss 